\title{
CHARACTERISTICS AND DISTRIBUTIONS OF NITROUS OXIDE-PRODUCING DENITRI- FYING FUNGI IN NATURAL ENVIRONMENTS
}

\section{K. Oishi and T. Kusuda}

Department of Civil Engineering, Faculty of Engineering, Kyushu University, Hakozaki 6-10-1, Higashi-ku, Fukuoka 812-8581, Japan

\begin{abstract}
Tea field soils, and sediments of an irrigation pond and a tidal river, in which a variety of organic matter was supplied as energy sources, were collected. The activities of bacterial and fungal denitrifications in these samples were determined. Denitrifying fungi in all of these samples produced $\mathrm{N}_{2} \mathrm{O}$ from nitrate and nitrite as a final product, whereas denitrifying bacteria produced $\mathrm{N}_{2}$. Nitrous oxide produced by fungi was reduced to $\mathrm{N}_{2}$ by bacteria. The fungal denitrification potentials were the highest in the submerged litter on the pond sediment, followed by the farmyard manure-amended soil, the inorganic fertilizer-amended soil, the litter-free pond sediment, and the tidal river sediment. The enrichments of denitrifying fungi in natural environments were related with the distributions of the organic material such as straws and litter. The contributions of fungal denitrification to total denitrification were large in soil environments, especially in the farmyard manure-amended soil, and were small in aquatic environments such as the sediments of pond and river. The $\mathrm{pH}$ in situ was not related with the fungal denitrification potentials.
\end{abstract}

Keywords fungal denitrification; bacterial denitrification; nitrous oxide; organic matter; sediments; soils

\section{Introduction}

Fungi generally are found in lakes, ponds, rivers, estuaries, marine, wastewater, and soils. Despite their wide occurrence, little attention has been given to the presence and ecological significance of fungi. Especially, characteristics and contributions of fungal denitrification in natural environments are poorly understood. Denitrification is a process in which nitrite and/or nitrate are reduced to $\mathrm{N}_{2}$ gas through $\mathrm{N}_{2} \mathrm{O}$. The process has been considered to be mainly caused by bacteria. However, pure culture experiments have shown that fungi such as Fusarium sp., Trichoderma hamatum, Chaetomium sp., Gibberella fujikuroi etc., can reduce nitrite and several strains can reduce nitrate as well, but the final product is mainly $\mathrm{N}_{2} \mathrm{O}$ rather than $\mathrm{N}_{2}$ ( Bleakley and Tiedje, 1982; Burth and Ottow, 1983; Shoun and Tanimoto, 1991; Shoun et al., 1992). The distributions of denitrifying fungi, which produce $\mathrm{N}_{2} \mathrm{O}$ as a final product, would be ecologically important to understand the contribution of natural systems to the atmospheric concentration of $\mathrm{N}_{2} \mathrm{O}$. Previous studies have been conducted with pure cultures of fungi. However, the characteristics and distributions of denitrifying fungi in natural environments are unknown.

In this study, tea soils, and the sediments of an irrigation pond and a tidal river, to which different types of organic matter were supplied, were collected. The final products of fungal denitrification in these soils and sediments were determined, and the distribution of denitrifying fungi in natural system was estimated.

\section{Materials}

\section{Tea field soils}

Soils were collected at the surface $(0-10 \mathrm{~cm})$ in two tea fields. One was mainly amended with a farmyard manure (organic soil), and the other with inorganic fertilizer only (inorganic soil). The farmyard manure was a compost of rice straws, grasses and cattle waste. The inorganic fertilizer was a mixture of ammonium phosphate, ammonium sulfate, potassium sulfate, fish meal, and rapeseed oil meal. Each soil was passed through a $2 \mathrm{~mm}$ mesh. The soils were freeze-dried and then an ignition loss at $600{ }^{\circ} \mathrm{C}$, and TC and TN contents by a Yanaco CHN analyzer MT-700 were measured (Table 1). Soil pH was determined in a soil-water suspension (1:2.5, at dry wt basis) (Tokuda and Hayatsu, 2000).

The irrigation pond is constructed in the tea plantation noted above. The water quality of the pond originates 
Table1 Characteristics of tea soils, the submerged litter and sediment of an irrigation pond, and the sediment of a tidal river used in this stduy

\begin{tabular}{|c|c|c|c|c|c|}
\hline & $\begin{array}{l}\mathrm{pH} \\
(-)\end{array}$ & $\begin{array}{l}\text { organic matter } \\
\text { contents* } \\
\qquad(\%)\end{array}$ & $\begin{array}{l}\mathrm{TC} \\
(\%)\end{array}$ & $\begin{array}{l}\mathrm{TN} \\
(\%)\end{array}$ & $\begin{array}{l}\mathrm{C} / \mathrm{N} \\
(-)\end{array}$ \\
\hline \multirow{3}{*}{$\begin{array}{l}\text { Tea soils } \\
\text { farmyard manure amended } \\
\text { chemical fertilizer amended }\end{array}$} & & & & & \\
\hline & 4.8 & 27.4 & 11.3 & 0.96 & 11.8 \\
\hline & 5.5 & 7.5 & 3.0 & 0.37 & 8.1 \\
\hline \multicolumn{6}{|l|}{ Irrigation pond } \\
\hline submerged litter & $6.9 * *$ & 75.7 & 41.5 & 1.98 & 21.0 \\
\hline sediment & 6.9 & 8.8 & 5.51 & 0.45 & 12.2 \\
\hline $\begin{array}{r}\text { Tidal river } \\
\text { sediment }\end{array}$ & 7.6 & 4.8 & 1.06 & 0.08 & 13.2 \\
\hline
\end{tabular}

from the tea soils. As the pond is surrounded by small deciduous trees, their leaves (litter) fall into the pond in every autumn, and the surface sediment in the pond becomes covered with them. The litter and surface sediments of the pond were collected in June. The litter on the surface sediment which had fallen in the last autumn retained the original form when collected. It was crushed with a blender. The residues, rigid and lignified stem buried in the sediment were partly degraded. They were removed from the sediments by sieve of $2 \mathrm{~mm}$. The contents of organic matter, TC and TN in the litter and the sediment were measured by the same procedures as those of soils. Sediment $\mathrm{pH}$ was measured in the supernatant after centrifuged at 1500xG for 10 minutes.

\section{Sediments of a tidal river}

Sediments were collected from the surface layer $(0-1 \mathrm{~cm})$ in a tidal zone and centrifuged at $1500 \mathrm{xG}$ for 10 minutes. A pH was measured in the supernatant. Then the solid was rinsed twice with a $0.1 \mathrm{M}$ phosphate buffer (in situ $\mathrm{pH}$ ). The contents of organic matter, TC and TN were measured by the same procedures used for the soils (Table 1 ).

\section{Methods}

\section{Preparation of samples}

Chloramphenicol and cycloheximide were used as specific growth inhibitors of bacteria and fungi, respectively (Anderson and Domsch, 1975; Newell et al., 1983; Fuhrman and McManus, 1984; Bjornsen, 1986). The samples were cultured in $0.1 \mathrm{M}$ phosphate buffer (in situ $\mathrm{pH}$ of each sample) containing the inhibitors (chloramphenicol and/or cycloheximide; $1 \mathrm{mg} / 50 \mathrm{~g}$ sample each) at $30{ }^{\circ} \mathrm{C}$ for 24 hours. Then the contamination of bacteria or fungi was tested using microscopy, and examined on heterotrophic agar plates and potato-dextrose agar plates using a spread plate technique.

\section{Measurements of bacterial, fungal, and the total denitrification potentials}

A suspension was prepared in a vial of $70 \mathrm{ml}$ volume. It contained a $3 \mathrm{~g}$ (as dry wt ) of each sample pretreated as described above, $3 \mathrm{ml}$ of $0.1 \mathrm{M}$ phosphate buffer (in situ $\mathrm{pH}$ of each sample), containing potassium nitrate or sodium nitrite and sodium fumarate at various concentrations, and $0.1 \mathrm{mg}$ of the same antibiotic as used for the pretreatment to continue the inhibition effect. Sodium fumarate was added as a supplement to avoid carbon limitation for denitrification rates (Sato et al., 1989; Sato and Matsumoto, 1990). The ratio of the fumarate to nitrate or nitrite was given at $\mathrm{C} / \mathrm{N}=2$. The vials were sealed with rubber septa and purged with $\mathrm{N}_{2}$ gas. These vials were divided into two groups. Acetylene $\left(\mathrm{C}_{2} \mathrm{H}_{2}\right)$ gas was added at $10 \mathrm{kPa}$ to one of them as a control (Yoshinari and Knowles, 1976; Yoshinari et al., 1977; Hynes and Knowles,1984 ). All experiments were carried out with at least five replicates. The vials were incubated by agitating gently to maintain the homoge- 

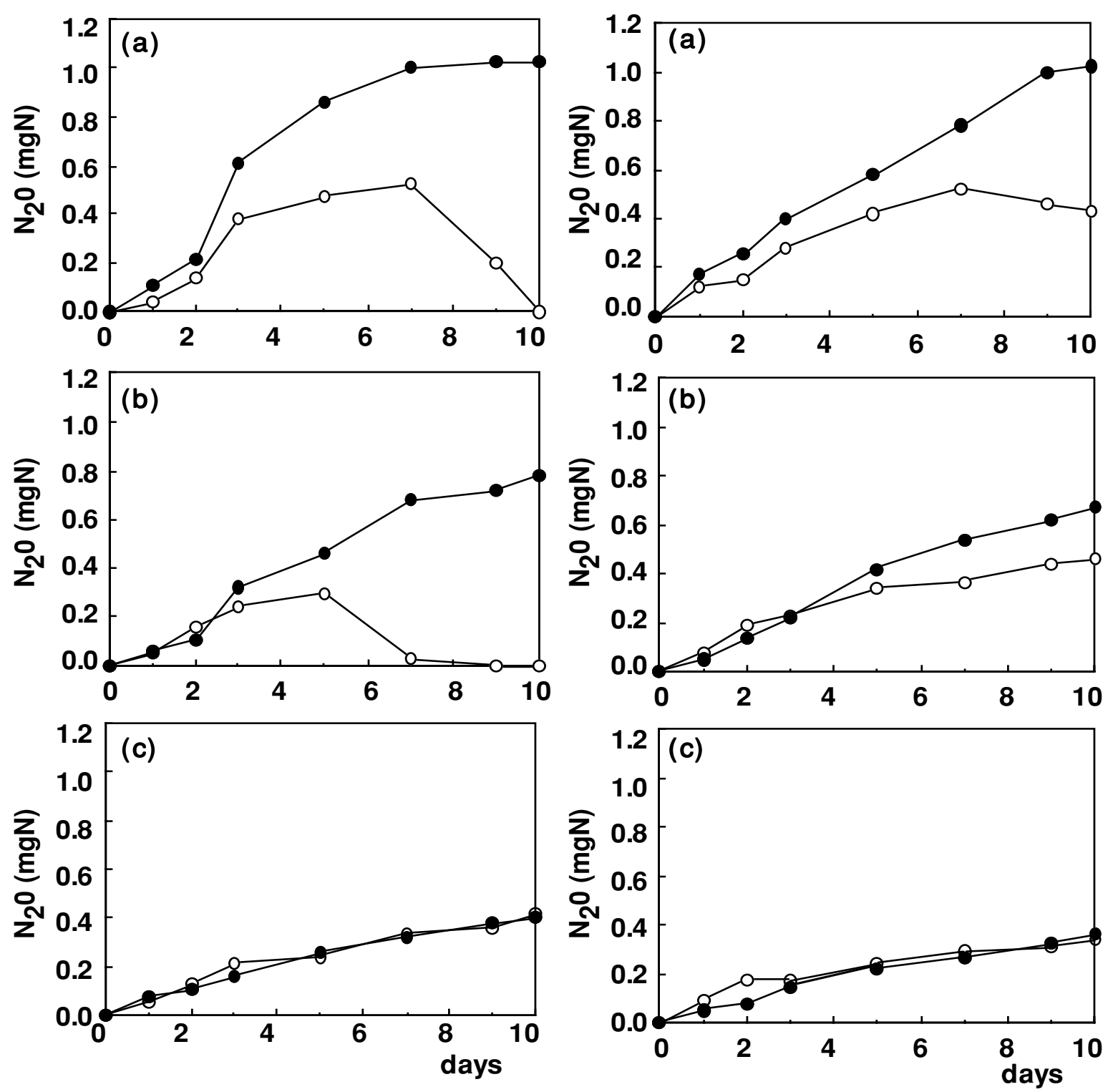

1) $\mathrm{N}_{2} \mathrm{O}$ produced by reduction of $\mathrm{NO}_{2}-\mathrm{N}$

2) $\mathrm{N}_{2} \mathrm{O}$ produced by reduction of $\mathrm{NO}_{3}-\mathrm{N}$

Figure 1 Behaviors of $\mathrm{N}_{2} \mathrm{O}$ produced from nitrate and nitrite by denitrification of a farmyard manure-amended soil at in situ $\mathrm{pH}$ in the absence and presence of $\mathrm{C}_{2} \mathrm{H}_{2}$.

(a) the intact soil, (b) the soil modified with cycloheximide, (c) the soil modified with chloramphenicol

The soil pretreated with chloramphenicol or cycloheximide and intact soil $\left(3 \mathrm{~g}\right.$ as dry wt) was incubated at $30^{\circ} \mathrm{C}$ with $3 \mathrm{ml}$ of 0.1 mole phosphate buffer $(\mathrm{pH}=5.0)$ containing $1 \mathrm{mgN}$ of nitrate or nitrite and sodium fumarate.

Open and solid symbols show $\mathrm{N}_{2} \mathrm{O}$ produced in the absence and presence of $\mathrm{C}_{2} \mathrm{H}_{2}$, respectively.

neity of the suspensions at $30{ }^{\circ} \mathrm{C}$ in the dark. The $\mathrm{N}_{2} \mathrm{O}$ concentrations in the vials were determined and denitrification rates were calculated from the $\mathrm{N}_{2} \mathrm{O}$ concentration in the control vials.

Finally, the suspensions were centrifuged at $1500 \mathrm{xG}$ for 10 minutes and the supernatants were filtered through $0.45 \mu \mathrm{m}$ pore size membranes. The filtrates were analyzed with a ChemLab autoanalyzer for nitrite and nitrate concentrations. The $\mathrm{pHs}$ were measured at the beginning and end of the experiment. The contamination of bacteria or fungi was tested by the same procedures as the beginning of the incubation.

\section{$\mathrm{N}_{2} \mathrm{O}$ analysis}

The $\mathrm{N}_{2} \mathrm{O}$ concentrations were determined with a Shimadzu gas chromatograph GC8A, equipped with an ECD, and molecular sieves 60/80 mesh-column (length $2 \mathrm{~m}$ ). Detector/injector and column temperatures were 330 ${ }^{\circ} \mathrm{C}$ and $200{ }^{\circ} \mathrm{C}$, respectively. The flow of carrier gas $\left(\mathrm{N}_{2}\right)$ was $30 \mathrm{ml} \mathrm{min}^{-1}$. The solubility of $\mathrm{N}_{2} \mathrm{O}$ in water at 30 ${ }^{\circ} \mathrm{C}$ was taken into account in the calculation of the resulting $\mathrm{N}_{2} \mathrm{O}$ concentration (Weiss and Price, 1980; Fogg and Gerrand, 1991). 


\section{Results}

Characteristics of fungal denitrification in sediments and soils

Figure 1 shows the behaviors of $\mathrm{N}_{2} \mathrm{O}$ produced from nitrite or nitrate by the intact soil and the soils modified with chloramphenicol or cycloheximide. In the absence of $\mathrm{C}_{2} \mathrm{H}_{2}$, the $\mathrm{N}_{2} \mathrm{O}$ produced by bacteria ((b) in Figure 1) disappeared completely at the earlier stage of the denitrification process, whereas the $\mathrm{N}_{2} \mathrm{O}$ produced by fungi ((c) in Figure 1) was approximately the same concentration as that in the presence of $\mathrm{C}_{2} \mathrm{H}_{2}$. The denitrifying fungi predominantly produced $\mathrm{N}_{2} \mathrm{O}$ as the final product as well as those of pure strains. The denitrifying bacteria produced $\mathrm{N}_{2} \mathrm{O}$ as a transient intermediate and the final product was $\mathrm{N}_{2}$. The denitrification rates of nitrite by denitrifying bacteria were slightly higher than those of nitrate. On the other hand, there is no difference in $\mathrm{N}_{2} \mathrm{O}$ production rates from nitrate and nitrite by fungi. The results from the organic soil were similar to those of all samples examined in this study.

\section{Contribution of fungal denitrification in natural environment}

The mass balance of nitrogen was calculated from the amounts of $\mathrm{N}_{2} \mathrm{O}$ and the residual nitrogen compounds (nitrate and nitrite) in the control vials in which $\mathrm{N}_{2} \mathrm{O}$ reduction was inhibited by $\mathrm{C}_{2} \mathrm{H}_{2}$. In all samples, the total recoveries of nitrogen compounds were more than $80 \%$. The sums of bacterial and fungal denitrifications nearly corresponded to the total denitrification. In addition, the samples pretreated with both chloramphenicol and cycloheximide neither utilized the substrates, nor produced $\mathrm{N}_{2} \mathrm{O}$ (not shown). Accordingly, the $\mathrm{N}_{2} \mathrm{O}$ was mainly produced by denitrifying bacteria and fungi.

Table 2 shows the bacterial, fungal and the total denitrification potentials at in situ $\mathrm{pH}$ and at $30{ }^{\circ} \mathrm{C}$, and the ratios of fungal denitrification to the total denitrification. The total denitrification potentials were the highest in the submerged litter $\left(670-720 \mu \mathrm{gN} \mathrm{g}^{-1} \mathrm{~d}^{-1}\right)$ followed by the tidal river sediment $\left(150-158 \mu \mathrm{gN} \mathrm{g}^{-1} \mathrm{~d}^{-1}\right)$, the organic soil (70-100 $\left.\mu \mathrm{gN} \mathrm{g}^{-1} \mathrm{~d}^{-1}\right)$, the sediment of the pond (56-67 $\left.\mu \mathrm{gN} \mathrm{g}^{-1} \mathrm{~d}^{-1}\right)$, and the inorganic soil (18-21 $\left.\mu \mathrm{gN} \mathrm{g}^{-1} \mathrm{~d}^{-1}\right)$. The fungal denitrification potentials were the highest in the submerged litter of the pond (56-68 $\left.\mu \mathrm{gN} \mathrm{g}^{-1} \mathrm{~d}^{-1}\right)$ followed by the organic soil $\left(22-27 \mu \mathrm{gN} \mathrm{g} \mathrm{g}^{-1}\right)$, the inorganic soil $\left(2.2-2.8 \mu \mathrm{gN} \mathrm{g}^{-1} \mathrm{~d}^{-1}\right)$, the pond sediment $\left(2-3 \mu \mathrm{gN} \mathrm{g}^{-1} \mathrm{~d}^{-1}\right)$, and the tidal river sediment $\left(<1 \mu \mathrm{gN} \mathrm{g}^{-1} \mathrm{~d}^{-1}\right)$. The ratios of fungal denitrification to the total denitrification were the largest in the soils, especially in the organic soil (23-38\%), and were small in the pond sediments $(3-5 \%)$ and the river sediments $(<0.6 \%)$. The submerged litter were the largest potentials in fungal denitrification, but the ratios to the total denitrification were $7.8-10 \%$ and the values were smaller than those in the soils.

\section{Discussion}

The determination of contributions of individual microorganism to total metabolism in an ecosystem has remained difficult because of methodological problems. The individual biomass and metabolic activity in the

Table 2 Potentials and contributions of bacterial and fungal denitrifications in tea soils, the submerged litter and sediment of an irrigation pond, and the sediment of a tidal river at in situ $\mathrm{pH}$.

\begin{tabular}{l|cccc} 
& Denitrification potential & $\left(\mu \mathrm{gN} \cdot \mathrm{g}^{-1} \cdot \mathrm{d}^{-1}\right)$ & $\begin{array}{c}\text { Fungal/Total } \\
\text { denitrification } \\
(\%)\end{array}$ \\
\cline { 2 - 5 } & Total & Bacterial & Fungal & $(\%)$ \\
\hline $\begin{array}{c}\text { Tea soils } \\
\text { farmyard manure amended } \\
\text { chemical fertilizer amended }\end{array}$ & $70 \sim 100$ & $48 \sim 62$ & $22 \sim 27$ & $23 \sim 38$ \\
$\begin{array}{l}\text { Irrigation pond } \\
\quad \text { litter } \\
\quad \text { sediment }\end{array}$ & $18 \sim 21$ & $14 \sim 16$ & $2.2 \sim 2.8$ & $10 \sim 15$ \\
$\begin{array}{c}\text { Tidal river } \\
\quad \text { sediment }\end{array}$ & $570 \sim 720$ & $610 \sim 710$ & $56 \sim 68$ & $7.8 \sim 10$ \\
& $56 \sim 67$ & $48 \sim 65$ & $2 \sim 3$ & $3 \sim 5$ \\
& $150 \sim 158$ & $148 \sim 156$ & $<1$ & $<0.6$
\end{tabular}

*Denitrification potentials were calculated from $\mathrm{N}_{2} \mathrm{O}$ production rates in the vials which $\mathrm{N}_{2} \mathrm{O}$ reduction was inhibited by $\mathrm{C}_{2} \mathrm{H}_{2}$ at $30{ }^{\circ} \mathrm{C}$ and in situ $p \mathrm{H}$ of each sample. 
complex ecosystems such as soils and aquatic environments can not be estimated without some destruction of the systems. The contributions of bacterial and fungal denitrifications were studied by using selective inhibitors in this study. Problems in this technique are also indicated by Newell et al. (1983) and Wu and Knowles (1995). Wu and Knowels (1995) reported that chloramphenicol affects denitrification activities of Flexibacter canadensis and Pseudomonas denitrificans. Furthermore, the sensitivities to inhibitors depended on the concentration, culture condition, and species of microorganisms. The results obtained by pure culture experiments couldn't be directly applied to natural samples. In this study, the bacterial and fungal denitrifications were measured after pretreatment with antibiotics. Accordingly, antibiotics might inhibit in part denitrification activities of some bacteria and fungi, but the degree of inhibition would be negligibly small. The denitrification potentials and the contributions shown in Table 2 do not always represent those in situ because of pretreatment, but would show relative rates and contributions of bacterial and fungal denitrifications.

It is normal for natural environments to be supplied with a variety of organic matter as energy sources. The predominant organisms in situ depend on the characteristics of organic matters. Samples collected in this study contained organic matters such as farmyard manure, litter, and detritus etc.. Generally, plant materials of terrestrial origin are rich in lignocellulose and lignin, which are hard to degrade biologically. Fungi are a major lignin degrader in the ecosystem, although some bacterial strains, the genera Nocardia, Streptmyces and Bacillus, can degrade lignin to $\mathrm{CO}_{2}$ (Crawford and Crawford, 1980). In this study, the fungal denitrification potentials were relatively high in the submerged litter of the pond and the organic soil, and were low in the inorganic soil, and the sediments of the pond and the tidal river (Table 2). The farmyard manure supplied to the tea soil was mainly composed of rice straws, grasses and cattle waste. Sakamoto and Oba $(1994,1995)$ reported that amendments such as straws and their composts selectively enriched fungi in soils, in comparison with amendments such as cattle feces and sewage sludge composts. Burdige and Martens (1988) reported that amino acids played an important role as available organic matters in coastal marine sediments. These organic matters, however, will not enrich fungi. The data suggest that the component of organic matters is one of the important factors involved in enrichment of denitrifying fungi. The inorganic fertilizer contains some organic matters such as fish meal and rapeseed oil meal, but these organics do not enrich denitrifying fungi. All bacteria and fungi do not have denitrification activities. Consequently, species and strains of denitrifying fungi were not identified, and the biomass was not determined, either.

Shoun et al. (1992) reported that most of denitrifying fungi could not reduce nitrate. However, the reduction of nitrate by fungi was the same degree as that of nitrite (Figure 1). The results suggest that a variety of denitrifying fungi, which can utilize nitrate and nitrite, is distributed in natural environments. Nitrous oxide produced by fungi seems to be reduced to $\mathrm{N}_{2}$ by bacteria (Figure 1). Denitrifying bacteria work as "sink" and "source" of $\mathrm{N}_{2} \mathrm{O}$, and fungi only work as "source". Therefore, the relative potentials and ratios of bacterial and fungal denitrifications are the important factors in controlling $\mathrm{N}_{2} \mathrm{O}$ emission in natural systems.

Most fungi are aerobic or microaerobic, although a few species show anaerobic metabolism (Tabak and Cooke, 1968). Therefore, it seems that the contributions of fungal denitrification to total denitrification are large in the soil environments (Table 2). Fungal denitrification also showed high potential at both the neutral $\mathrm{pH}$ (i.e. the sediments) and the low $\mathrm{pH}$ (i.e. the soils). A low $\mathrm{pH}$ value affected bacterial denitrification, but not fungal denitrification (Oishi and Kusuda, 1997). Anderson and Domsch (1975) also suggested that the degree of fungal dominance was not dependent on the $\mathrm{pH}$ of the soil. Therefore enrichment of denitrifying fungi would depend on the components of available organic matter rather than $\mathrm{pH}$.

\section{Conclusions}

A variety of denitrifying fungi was distributed in natural environments, and can utilize not only nitrite but also nitrate. The denitrifying fungi were enriched in the environment which the organic material such as straws and litter was supplied. Nitrous oxide produced by fungi was reduced to $\mathrm{N}_{2}$ by bacteria in natural environments. The contributions of fungal denitrification to total denitrification were larger in soils than those in aquatic environments.

\section{References}

Anderson J.P.E. and K.H. Domsch (1975). Measurement of bacterial and fungal contributions to respiration of 
selected agricultural and forest soils. Canadian Journal of Microbiology, 21, 314-322.

Bjornsen P.K. (1986). Bacterioplankton growth yield in continuous seawater cultures. Marine Ecology Progress Series, 30, 191-196.

Bleakley B.H. and J. M. Tiedje (1982). Nitrous oxide production by organisms other than nitrifiers and denitrifiers. Applied and Environmental Microbiology, 44, 1342-1348.

Burdige J. D. and C. S. Martens (1988). Biogeochemical cycling in an organic-rich coastal marine basin: 10. The role of amino acids in sedimentary carbon and nitrogen cycling. Geochimica et Cosmochimica Acta, 52, 1571-1584.

Burth I. and J.C.G. Ottow (1983). Influence of $\mathrm{pH}$ on the production of $\mathrm{N}_{2} \mathrm{O}$ and $\mathrm{N}_{2}$ by different denitrifying bacteria and Fusarium solani. Ecological Bulletin, 35, 207-215.

Crawford D. L. and R. L. Crawford (1980). Microbial degradation of lignin. Enzyme Microbial Technology, 2, 11-22.

Fogg P.G.T. and W. Gerrand (1991). Solubility of gasses in liquids. A critical evaluation of gas/liquid systems in theory and practices, Wiley New York.

Fuhrman J.A. and G.B. McManus (1984). Do bacteria-sized marine eucaryotes consume significant bacterial production? Science, 24, 1257-1260.

Hynes R.K. and R. Knowles (1984). Production of nitrous oxide by Nitrosomonas europaea: effects of acetylene, pH and oxygen. Canadian Journal Microbiology, 30,1397-1404.

Newell S.Y., B.F. Sherr, E.B. Sherr and R.D. Fallon (1983). Bacterial response to presence of eukaryote inhibitors in water from a coastal marine environment. Marine Environmental Research, 10, 147-157.

Oishi K. and T. Kusuda (1997). Effects of bacteria and fungi on $\mathrm{N}_{2} \mathrm{O}$ concentration produced by denitrification in soil environments. Environmental Engineering Research, 34, 35-40.

Sakamoto K. and Y. Oba (1994). Effect of fungal to bacterial biomass ratio on the relationship between $\mathrm{CO}_{2}$ evolution and total soil microbial biomass. Biology and Fertility of Soils. 17, 39-44.

Sakamoto K. and Y. Oba (1995). Effect of various amendments on microbial biomass flora in arable soil. Japanese Journal of Soil Science and Plant Nutritions, 66, 418-421.

Sato R., S. Matsumoto and H. Wada (1989). Promoting effects of organic compounds on denitrification in sewage treatment. Environmental Science. 2, 79-86.

Sato R. and S. Matsumoto (1990). Problem in addition of fumarate to promote denitrification in sewage treatment. Environmental Science. 3, 219-222.

Shoun H. and T. Tanimoto (1991). Denitrification by the fungus Fusalium oxysporum and involvement of cytochrome P-450 in the respiratory nitrite reduction. The Journal of Biological Chemistry, 266, 1107811082.

Shoun H., D. Kim, H. Uchiyama and J. Sugiyama (1992). Denitrification by fungi. FEMS Microbiology Letters, 94, 277-282.

Tabak H. and W.B. Cooke (1968). Growth and metabolism of fungi in an atmosphere of nitrogen. Mycologia. 60, 115-140.

Tokuda S. and M. Hayatsu (2000). Nitrous oxide production from strongly acid tea field soils. Soil Science and Plant Nutrtion, 46, (4), 835-844.

Weiss R.F. and B.A. Price (1980). Nitrous oxide solubility in water and seawater. Marine Chemistry, 8, 347 359.

Wu O. and R. Knowles (1995). Effect of choramphenicol on denitrification in Fluexibacter canadensis and "Pseudomonas denitrificans". Applied and Environmental Microbiology, 61, 434-437.

Yoshinari T. and R. Knowles (1976). Acetylene inhibition of nitrous oxide reduction by denitrifying bacteria. Biochemical and Biophysical Research Communication, 69, 705-710.

Yoshinari T., R. Hynes, and R. Knowles (1977). Acetylene inhibition of nitrous oxide reduction and measurement of denitrification and nitrogen fixation in soil. Soil Biology and Biochemistry, 9, 177-183. 